\title{
Calculation of Liquidity, Solvency and Profitability Ratio in Manufacturing Company
}

\author{
Rally Ferry Agusta ${ }^{a *}$, Shinta Wahyu Hati ${ }^{\mathrm{b}}$ \\ a Jurusan Manajemen Bisnis, Politeknik Negeri Batam, actrally@gmail.com, Indonesia \\ bJurusan Manajemen Bisnis, Politeknik Negeri Batam, shinta@polibatam.ac.id, Indonesia
}

\begin{abstract}
This research discuss the calculation of liquidity, solvency and profitability ratios. The liquidity ratio is the ratio that describes the company's ability to meet short-term liabilities, solvency ratio is the ratio that describes the company's ability to meet long-term obligations and the profitability ratio is the ratio that measures the company's ability to generate profits. The aim of this final project is to find out the company's financial condition. The collection of data was used secondary techniques of data in the form of statement of financial position and income statement. The method of analysis used on this study is descriptive analysis method is done by creating a picture and interpret the data relating to fact, circumstances, variable and ongoing events at the time of study. The results obtained after performing the calculation of liquidity, solvency and profitability ratios is the condition of the company based on the liquidity and solvency ratios is in proper and healthy, meanwhile the company is in bad condition based on profitability ratio's view.
\end{abstract}

Keywords: liquidity ratio, solvency ratio and profitability ratio

\section{Introduction}

Today's economic growth in Indonesia in an effort to experience significant increases. It is also experienced by the Batam city that became one of the cities with rapid economic growth. Batam city as one of the industry in Indonesia has some considerable industrial region in which there are various types of industries including manufacturing. An effort to process or convert raw materials into finished or semifinished goods that have added value, which is done mechanically using a machine called a manufacturing company.

Manufacturing industry competition requires companies to be more assertive in improving the ability of the company, especially financially. The company's ability to improve financial capability can be seen from the financial statements annually. In assessing the achievements of the company can be found on the company's financial performance as reflected in the financial statements. According to Fahmi (2011), understanding financial statements is an information describing the financial condition of a company, which would later become an information that describes the performance of a company. Further according to Munawir (in Fahmi, 2011), the financial statements is a very important tool to obtain information relating to the financial position and the results that have been achieved by the company concerned. The financial statements consist of the statement of financial position, income statement, statement of changes in equity, cash flow statement and notes of financial position.

It is undeniable that the company's financial statements need to be analyzed to determine the company's financial performance. Financial analysis involves an assessment of the financial companies in the past, present and future. The assessment is

*Corresponding author. E-mail: actrally@ gmail.com 
intended to find weaknesses in the company's financial performance which may lead to problems for the company, from this assessment is also expected to problems that arise can be fixed and the results were deemed good enough in times past can maintained for the foreseeable future.

Analyzing financial data needs to be a certain size and one of the most commonly used measure is the financial ratios. Financial ratios can be calculated from the contents of the financial information in the financial statements that show the strength of the company. According Wibowo and Pujiati (2011), the financial ratio is an analysis tool that is used to compare the figures contained in the financial statements by dividing one number by another number. In general, financial ratios are most often used is the ratio of liquidity, solvency ratios, activity ratios and profitability ratios.

Sample company is a manufacturing company whose main orientation is entertainment electronic components such as speakers, microphone and headphones. Sample company produces products ranging from raw materials, work in process to become finished goods. Sales of the production company only sold to the parent company in Singapore. Like the other companies of the company's common objectives in the short term profit, while in the long term is to increase the expansion. The success of a company is generally measured by the rate of profit, so that profit can be realized then the company must be able to demonstrate the ability to manage resources and facilities owned as efficiently.

Analysis of the financial statements should be created to measure and assess the extent of progress or decline of the company's financial performance. One measure that is most often used in financial statement analysis is a financial ratio. According the background issues that have been described previously, the authors identify problems that test the financial performance of company whether healthy or not in terms of the liquidity, solvency and profitability ratios.

\section{Literature Review}

According to the Indonesian Institute of Accountants (2015), the financial statements are part of the financial reporting process. Complete financial statement normally includes a statement of financial position, income statement, statement of changes in financial position (which may be expressed in various ways such as cash flow statement or statement of fund flows), notes and other statements and explanatory material that are an integral part of these financial statements. The purpose of financial statements is to provide information regarding the financial position, performance and changes in financial position of an entity that is beneficial to a large number of users in making economic decisions. Meanwhile, according Sujarweni (2017), the financial statements are records of financial information of an enterprise in an accounting period can be used to describe the company's financial performance. It can be concluded that the financial statements are the result of the accounting process at the end of the period.

According Sujarweni (2017), the types of financial reports are grouped into five, namely:

1. Statement of Financial Position

2. Income statement

3. Statement of Changes in Equity

4. Cash Flow Statement

5. Notes of Financial Statements.

According Munawir (in Sujarweni, 2017), financial statement analysis is the analysis of financial statements consisting of a review or study than the relationship and the tendency or the trend to determine the financial position and results of operations and the development of the company concerned. Meanwhile, according Wild (in Sujarweni, 2017), financial statement analysis is the application of tools and techniques for the analysis of general purpose financial statements and related data to generate estimates and conclusions that are useful in business analysis. So it can be concluded that the financial statement analysis are tools and analysis techniques for financial statements along with related data to produce information more widely and more in the related financial statements, so the results of financial statements can serve as the basis for decision making for the parties concerned in the future.

According Munawir (in Sujarweni, 2017), the purpose of financial statement analysis is a very important tool to obtain information relating to the financial position and the results that have been achieved by the company concerned. Financial data will be more meaningful for the parties concerned if the data is comparable for the two periods or more, and further analysis so that would be obtained data to be able to support the decision to be taken. Further, according to Prasnanugraha (in Ottay and Alexander, 2015), the analysis of financial statements is useful as an internal analysis for corporate management to know the financial result achieved for future planning as well as for internal analysis for creditors and investors to determine credit policy and investment of a company. 
According to Kasmir (2016), the types of financial ratios, namely:

1. Liquidity ratios
a. Current Ratio
b. Quick Ratio
c. Ratio Cash

2. Solvency ratios
a. Debt to Equity Ratio (DER)
b. Debt to Assets Ratio (DAR)
3. Profitability ratios
a. Net Profit Margin (NPM)
b. Return on Equity (ROE)
c. Return on Investment (ROI)

\section{Research Design}

Recognizing the breadth of scope of the research, then in this final project the authors limited the problem as follows: Discuss issues relating to the analysis of financial statements of the company, especially its liquidity ratio, solvency and profitability ratios; The data used is the company's financial statements in particular the statement of financial position and income statement of 2015 and 2016; This research was conducted in the Accounting Department at PT ABC Indonesia.

\section{Results and Discussion}

\section{Statement of Financial Position and Income}

The statement of financial position company which have been exchanged into Rupiah are presented in Table 1.

Table 1 Statement of Financial Position (million rupiah)

\begin{tabular}{lrr}
\hline \multicolumn{1}{c}{ Accounts } & \multicolumn{1}{c}{2015} & \multicolumn{1}{c}{2016} \\
\hline Current Assets & & \\
Cash and Deposits & 1.033 .831 & 1.988 .341 \\
Finished Goods & 2.177 .437 & 1.863 .039 \\
Raw Materials & 1.074 .636 & 794.662 \\
Work in Process & 139.144 & 148.051 \\
Others & 4.448 .159 & 3.626 .053 \\
Total Current Assets & 8.873 .568 & 8.420 .748 \\
Non-Current Assets & & \\
Property, Plant and Equipment & 2.801 .058 & 2.647 .470 \\
Intangible Assets & 211.364 & 184.522 \\
Investment and Other Assets & 733.034 & 631.084 \\
Total Non-Current Assets & 3.745 .938 & 3.463 .558 \\
Total Assets & 12.619 .627 & 11.884 .426 \\
\hline \multicolumn{2}{c}{} \\
\hline Current Liabilities & 3.815 .510 & 3.504 .001 \\
Long-Term Liabilities & 986.068 & 313.556 \\
Total Liabilities & 4.802 .519 & 3.817 .677 \\
\hline
\end{tabular}

\begin{tabular}{lrr}
\hline \multicolumn{1}{c}{ Accounts } & \multicolumn{1}{c}{2015} & \multicolumn{1}{c}{2016} \\
\hline Equity & & \\
Common Stock & 814.884 & 814.884 \\
Capital surplus & 1.128 .079 & 1.128 .079 \\
Retained Earnings & 4.757 .863 & 5.409 .770 \\
Treasury Stock & $(16.009)$ & $(16.009)$ \\
Others & 1.132 .051 & 729.664 \\
Total Equity & 7.817 .108 & 8.066 .629 \\
Total Liabilities and Equity & 12.619 .627 & 11.884 .426 \\
\hline
\end{tabular}

The Income Statement which have been exchanged into Rupiah are presented in Table 2.

Table 2 Income Statement (million rupiah)

\begin{tabular}{lrr}
\multicolumn{3}{c}{ Table 2 Income Statement (million rupiah) } \\
\hline \multicolumn{1}{c}{ Accounts } & \multicolumn{1}{c}{2015} & \multicolumn{1}{c}{2016} \\
\hline Net Sales & 22.764 .270 & 22.981 .411 \\
Cost of Sales & 19.545 .418 & 19.725 .246 \\
Gross Profit & 3.218 .731 & 3.256 .165 \\
Selling, General \& Adm. Exp. & 2.045 .395 & 16.701 .120 \\
Operating Income & 1.173 .216 & 1.245 .918 \\
Non-Operating Income & 159.125 & 129.033 \\
Non-Operating Expenses & 80.766 & 69.331 \\
Ordinary Income & 1.251 .575 & 1.305 .620 \\
Extraordinary Income & 19.259 & 86.544 \\
Extraordinary Losses & 185.245 & 189.939 \\
Income Before Income Taxes & 1.085 .589 & 1.202 .345 \\
Total Income Taxes & 444.033 & 314.158 \\
Net Income & 641.556 & 888.067 \\
\hline
\end{tabular}

\section{Liquidity Ratio Calculation}

To calculate the ratio of liquidity consisting of Current Ratio, Quick Ratio, and Cash Ratio required financial statements relating to current assets, current liabilities, inventory and cash or cash equivalents.

a. Current Ratio

Is a ratio to measure a company's ability to pay short-term obligations or any immediately due upon being billed as a whole. In other words, how many assets are available to cover short-term liabilities that is due soon. Here are the results of the calculation of the current ratio of company are presented in Table 3.

\begin{tabular}{|c|c|c|c|}
\hline Year & $\begin{array}{c}\text { Current asset } \\
1\end{array}$ & $\begin{array}{c}\text { Current liabilities } \\
2\end{array}$ & $\begin{array}{c}\text { Current Ratio } \\
1: 2\end{array}$ \\
\hline 2015 & 8.873 .568 & 3.815 .510 & $233 \%$ \\
\hline 2016 & 8.420 .748 & 3.504 .001 & $240 \%$ \\
\hline
\end{tabular}

Based on the current ratio calculation results in Table 3, explaining that any one company's current debt rupiah will be secured by the value of the current ratio in each year. This means that, by 2015 every 1 rupiah current debts guaranteed by 2.33 (233\%) of current assets rupiah, while in 2016 every 1 rupiah current debts guaranteed by $2.40(240 \%)$ of current assets rupiah. Based on the calculation, there is an 
increase in the ratio of 2016 by $7 \%$ to $240 \%$, which in previous years were diangka ratio of $233 \%$.

b. Quick Ratio

Is a ratio that measures the company's ability to meet or pay liabilities or current liabilities with current assets without taking into account the value of inventory? Here are the results of the calculation quick ratio is presented in Table 4.

Table 4 Results of Quick Ratio Calculation period 2015-2016

\begin{tabular}{cccccc}
\hline Year & $\begin{array}{c}\text { Current } \\
\text { asset }\end{array}$ & $\begin{array}{c}\text { Inventory } \\
1\end{array}$ & $\begin{array}{c}\text { Amount of } \\
1-2\end{array}$ & $\begin{array}{c}\text { Current } \\
\text { liabilities }\end{array}$ & $\begin{array}{c}\text { Quick } \\
\text { Ratio } \\
3: 4\end{array}$ \\
\hline 2015 & 8.873 .568 & 3.391 .217 & 5.482 .351 & 3.815 .510 & $144 \%$ \\
2016 & 8.420 .748 & 2.805 .752 & 5.614 .996 & 3.504 .001 & $160 \%$ \\
\hline
\end{tabular}

Based on quick ratio calculation results in Table 4, there is a rise in the ratio in 2016 of $16 \%$ to $160 \%$, by 2015 the ratio stood at $144 \%$. Quick ratio calculation results make it clear that any one company's current debt rupiah will be secured by the value of quick ratio results in each year.

c. Cash Ratio

Is a tool used to measure how much cash is available to repay debt? Availability of cash can be shown on the availability of cash or cash equivalents as current accounts or savings in the bank (which can be withdrawn at any time). Here are the results of the calculation of the cash ratio are presented in Table 5.

Table 5 Results of Cash Ratio Calculation on period 2015-2016

\begin{tabular}{cccc}
\hline \multirow{2}{*}{ Year } & Cash + Bank & Current liabilities & Cash Ratio \\
& 1 & 2 & $1: 2$ \\
\hline 2015 & 1.033 .831 & 3.815 .510 & $27 \%$ \\
2016 & 1.988 .341 & 3.504 .001 & $57 \%$ \\
\hline
\end{tabular}

Based on the cash ratio calculation results in Table 5 , there is a rise in the ratio of $30 \%$, which in 2015 was diangka ratio of $27 \%$ after an increase in 2016 the ratio was at $57 \%$. It is also clear that any one company's current debt rupiah will be secured by the value of the cash ratio in each year. Cash ratio is considered to be the calculation of financial ratios that are very effective because the cash ratio using cash and cash equivalents of the company to be compared with current liabilities.

\section{Solvency Ratio Calculation}

To calculate the solvency ratio consisting of Debt to Equity Ratio and Debt to Assets Ratio required financial statements related to the amount of debt, equity and assets.

a. Debt to Equity Ratio
Is a ratio used to assess the debt for equity? This ratio is calculated by comparing the entire debt including current debts with the rest of the equity. This ratio is useful to know the amount of funds provided the borrower with the owner of the company. Here are the results of the calculation of the debt to equity ratio presented in Table 6.

\begin{tabular}{|c|c|c|c|}
\hline Year & $\begin{array}{c}\text { Total Debt } \\
1\end{array}$ & $\begin{array}{c}\text { Total Equity } \\
2\end{array}$ & $\begin{array}{c}\text { DER } \\
1: 2\end{array}$ \\
\hline 2015 & 4.802 .519 & 7.817 .108 & $61 \%$ \\
\hline 2016 & 3.817 .677 & 8.066 .629 & $47 \%$ \\
\hline
\end{tabular}

Based on the calculation of debt to equity ratio in Table 6, show that creditors provide IDR61.00 in 2015 to IDR100.00 supplied each shareholder. Companies financed by debt as much as $61 \%$. Meanwhile, in 2016 the creditor presents IDR47.00 for IDR100.00 supplied to each shareholder, the company is financed by debt as much as $47 \%$.

b. Debt to Assets Ratio

This ratio is the ratio of debt used to measure the ratio between total debts by total assets. In other words, how much of the company's assets is financed by debt or how debt affects the asset management company. Here are the results of the calculation of debt to assets ratio presented in Table 7.

Table 7 Calculation Results DAR period in 2015-2016

\begin{tabular}{cccc}
\hline \multirow{2}{*}{ Year } & Total Debt & Total Assets & DAR \\
& 1 & 2 & $1: 2$ \\
\hline 2015 & 4.802 .519 & 12.619 .627 & $38 \%$ \\
2016 & 3.817 .677 & 11.884 .426 & $32 \%$ \\
\hline
\end{tabular}

Based on the calculation of debt to assets ratio in Table 7 shows that $38 \%$ of companies financed with debt financing for 2015. This means that every IDR100.00 funding company, IDR38.00 financed with debt and IDR62.00 was provided by shareholders. Meanwhile, in 2016 the company financed with debt of $32 \%$. That is, each IDR 100.00 funding company, IDR32.00 financed with debt and IDR68.00 was provided by shareholders.

Calculation of Ratio Profitability in PT ABC Indonesia

To calculate the profitability ratio consists of Net Profit Margin, Return on Equity and Return on Investment required financial statements related to the amount of profit after interest and tax, sales, equity and assets. 


\section{a. Net Profit Margin}

Is a ratio used to measure the benefit by comparing the profit after interest and taxes compared with sales? Here are the results of the calculation of net profit margin PT ABC Indonesia presented in Table 8.

\begin{tabular}{cccc}
\multicolumn{4}{c}{ Table 8 Calculation Results NPM period in } \\
\hline \multirow{2}{*}{ Year } & EAIT & Sales & NPM \\
& 1 & 2 & $1: 2$ \\
\hline 2015 & 641.556 & 22.764 .270 & $3 \%$ \\
2016 & 888.067 & 22.981 .411 & $4 \%$ \\
\hline
\end{tabular}

Based on the calculations in Table 8 , the profit margin obtained by the company in 2015 was $3 \%$. Furthermore, for 2016 the company's profit margin rose to $4 \%$, there is a rise in the ratio of $1 \%$, this happens because the net income and net sales increased. That is, in 2016 companies can reduce costs not necessary, so the company is able to maximize the net profit obtained.

b. Return on Equity

Is a ratio which indicates the efficiency of use of capital own? The higher this ratio, the better. That is the position of the owner of the company is getting stronger, and vice versa. Here are the results of the calculation of return on equity presented in Table 9.

\begin{tabular}{|c|c|c|c|}
\hline Year & $\begin{array}{c}\text { EAIT } \\
1\end{array}$ & $\begin{array}{c}\text { Total Equity } \\
2\end{array}$ & $\begin{array}{c}\mathrm{ROE} \\
1: 2\end{array}$ \\
\hline 2015 & 641.556 & 7.817 .108 & $8 \%$ \\
\hline 2016 & 888.067 & 8.066 .629 & $11 \%$ \\
\hline
\end{tabular}

Based on the calculation of return on equity in Table 9, 2015 showed that the return on investment from the company amounted to $8 \%$. Then, in 2016 increased to $11 \%$ an increase of $4 \%$, this was due to net income and equity of the company increased. That is, the company is able to maximize the return on equity to net income.

c. Return on Investment

Is a ratio that shows the results (return) on the amount of assets used in the company? The result of investment returns showed the productivity of the entire fund companies, both equity and loan capital. Here are the results of the calculation of return on investment presented in Table 10.

Table 10 Results of calculation of ROI period in 2015-2016

\begin{tabular}{cccc}
\hline \multirow{2}{*}{ Year } & EAIT & Total assets & ROI \\
& 1 & 2 & $1: 2$ \\
\hline 2015 & 641556 & $12,619,627$ & $5 \%$ \\
2016 & 888067 & $11,884,426$ & $7 \%$ \\
\hline
\end{tabular}

Based on the calculation of return on investment in Table 10, in 2015 showed that the return on investment from the company amounted to $5 \%$. Then, in 2016 rose to $7 \%$, an increase of $2 \%$, this was due to the net profit in 2016 increased.

\section{Results Calculation Similar Industry Average}

Here are the results of the calculation of average similar industries, financial reporting data used comes from the Indonesia Stock Exchange (www.idx.co.id), as follows.

Table 11 Similar Industry Average Liquidity Ratio

\begin{tabular}{lcc}
\hline \multicolumn{1}{c}{ Ratios } & 2015 & 2016 \\
\hline Current Ratio & $174 \%$ & $191 \%$ \\
Quick Ratio & $117 \%$ & $134 \%$ \\
Cash Ratio & $13 \%$ & $31 \%$ \\
\hline
\end{tabular}

Table 12 Similar Industry Average Solvency Ratio

\begin{tabular}{ccc}
\hline Ratios & 2015 & 2016 \\
\hline Debt to Equity Ratio & $127 \%$ & $110 \%$ \\
Debt to Assets Ratio & $50 \%$ & $47 \%$ \\
\hline
\end{tabular}

Table 13 Similar Industry Average Profitability Ratios

\begin{tabular}{lcc}
\multicolumn{3}{c}{ Table 13 Similar Industry } \\
\hline \multicolumn{1}{c}{ Ratios } & 2015 & 2016 \\
\hline Net Profit Margin & $4 \%$ & $6 \%$ \\
Return on Equity & $15 \%$ & $19 \%$ \\
Return on Investment & $6 \%$ & $9 \%$ \\
\hline
\end{tabular}

\section{Results Calculation and Analysis liquidity ratio}

Here are the results of measurements liquidity ratios presented in Table 14.

Table 14 Measurement of Liquidity Ratio

\begin{tabular}{lccccc}
\hline \multirow{1}{*}{ Ratios } & 2015 & 2016 & $\begin{array}{c}\text { Industry } \\
\text { standards }\end{array}$ & \multicolumn{2}{c}{ Industry standards } \\
& & & (Similiar company) \\
(Kasmir) & 2015 & 2016 \\
\hline Current Ratio & $233 \%$ & $240 \%$ & $200 \%$ & $174 \%$ & $191 \%$ \\
Quick Ratio & $144 \%$ & $160 \%$ & $150 \%$ & $117 \%$ & $134 \%$ \\
Cash Ratio & $27 \%$ & $57 \%$ & $50 \%$ & $13 \%$ & $31 \%$ \\
\hline
\end{tabular}

According to the Table 14 above, the Current Ratio companies when measured using industry standard in Kasmir (2016), in 2015 and 2016 the condition of the company in good shape and healthy because the value of the ratio is above the industry average. In addition, when measured using the average of industry peers, then the condition of the company in good shape and healthy, considering the ratio is above average.

When measured using industry standard in Kasmir (2016), then the state of the company in 2015 and 2016 were in good shape and healthy, considering the ratio is above the industry average. In addition, when 
measured using the average of industry peers, then the condition of the company in 2015 and 2016 were in good shape and healthy, because the ratio which is above the industry average. This indicates that if the company wanted to pay off its current liabilities, can be done by selling the securities or collect accounts receivable, without having to sell the stock of the company.

When measured using industry standard in Kasmir (2016), then the condition of the company in 2015 in bad conditions, considering the ratio below the industry average, while in 2016 the condition of the company in good shape and healthy, because the ratio is above the industry average. In addition, when measured using the industry average of its peers, the company's condition by 2015 and 2016 in good shape and healthy, because the ratio is above average.

\section{Results Solvency Ratio Calculation and Analysis}

Here are the results of measurements solvency ratios presented in Table 15 .

Table 15 Measurement of Solvency Ratio

\begin{tabular}{lccccc}
\multicolumn{2}{c}{ Table 15 Measurement of Solvency Ratio } \\
\hline $\begin{array}{l}\text { Type of } \\
\text { Ratios }\end{array}$ & 2015 & 2016 & $\begin{array}{c}\text { Industry } \\
\text { standards }\end{array}$ & \multicolumn{2}{c}{$\begin{array}{c}\text { Industry standards } \\
\text { (similiar company) }\end{array}$} \\
\hline DER & $61 \%$ & $47 \%$ & $90 \%$ & $127 \%$ & $110 \%$ \\
DAR & $38 \%$ & $32 \%$ & $35 \%$ & $50 \%$ & $47 \%$ \\
\hline
\end{tabular}

Based on the above Table 15, Debt to Equity (DER) Ratio when measured using the industry average by Kasmir (2016), the company in 2015 and 2016 in good shape and healthy because the ratio is below the industry average. In addition, when measured using the industry average of its peers, the company is in good shape and healthy considering the ratio is below the industry average. This indicates that the company has a smaller debt than equity owned.

Debt to Assets Ratio (DAR), when measured using the industry average by Kasmir (2016), the company in 2015 in conditions that are unfavorable because the ratio is above or exceeds the industry average, but for 2016, the condition of the company is considered a good and healthy, because the ratio is below the industry average. Meanwhile, when measured using the average of industry peers, then the condition of the company in good shape and healthy because the ratio is below the industry average. This indicates that the company financed with debt not exceeding the industry average.

\section{Results Calculation and Analysis Ratios Profitability}

Here are the results of measurements profitability ratios presented in Table 16.

Table 16 Results of Measurement of Profitability Ratios

\begin{tabular}{lccccc}
\hline $\begin{array}{c}\text { Type of } \\
\text { Ratios }\end{array}$ & 2015 & 2016 & $\begin{array}{c}\text { Industry } \\
\text { standards } \\
\text { (Kasmir) }\end{array}$ & \multicolumn{2}{c}{$\begin{array}{c}\text { Industry standards } \\
\text { (similiar company) }\end{array}$} \\
\hline NPM & $3 \%$ & $4 \%$ & $20 \%$ & $4 \%$ & $6 \%$ \\
ROE & $8 \%$ & $11 \%$ & $40 \%$ & $15 \%$ & $19 \%$ \\
\hline
\end{tabular}

According to the Table 16 above, Net Profit Margin (NPM) company when measured using the industry average by Kasmir (2016), the company's profit margin in 2015 and 2016, is not considered good because below the industry average. It can also mean that the price of goods the company is relatively low or relatively high fees and charges, or both. Meanwhile, when measured using the industry average of its peers, the company is not considered good condition because both are below the industry average. This indicates that the company has not been able to minimize the burden associated directly to sales.

Return on Equity (ROE), as measured using the industry average by Kasmir (2016), then the condition of the company is not good because the ratio in 2015 and 2016 were below the industry average. In addition, when measured using the average of industry peers, then the condition of the company is also in good condition because it is below the industry average. Even so, the value of the ratio of ROE has increased from the previous year, indicating that the company is able to maximize the return on equity to net income and the company can satisfy the interests of shareholders.

Return on Investment (ROI), as measured using the industry average by Kasmir (2016), the company's profit margin in 2015 and 2016 are considered not good, because the ratio is still below the industry average. Meanwhile, when measured using the industry average of its peers, the company's profit margin conditions for the second year is considered not good, because it is still below the industry average. Even so, the value of the ratio of ROI has increased from the previous year, indicating that the company is able to utilize its assets properly, resulting in profits for the company. 


\section{Conclusion}

Based on these discussions, it could be concluded as follows:

Condition of the company in terms of overall liquidity ratios are in good shape and healthy. It can be seen from the development value of the current ratio and quick ratio in 2015 and 2016 which was above the industry average in Kasmir (2016) as well as the industry average of its peers. Cash value ratio in 2015 was below the industry average, according Kasmir (2016), however in 2016 the value of the cash ratio increases, so that the value is above the industry average. The Company is able to meet its short-term debt.

Condition of the company in terms of the overall solvency ratio was in good shape and healthy. It can be seen from the development value of the debt to equity ratio in 2015 and 2016 were always under the industry average, means the company has less debt than equity owned. In addition, the development of the value of debt to assets ratio is also in good shape, considering the overall value is below the industry average.

Condition of the company in terms of overall profitability ratios in an unhealthy condition. It can be seen from the development value of the ratio of net profit margin, return on equity and return on investment that is always under the industry average, both the industry average and the average Cashmere similar industries. Although the value of the ratio of net profit margin, return on equity and return on investment in 2015 and 2016 were always below the industry average, but the value of the ratio is always increase from the previous year, indicating the company is able to generate profits.

Generally seen from the three financial ratios, the company can carry out its activities effectively and efficiently because of the increased value of each ratio, which shows the improved performance of the company in managing its financial resources.

As for the suggestion that the author wants to give to the company are: Companies should further improve current assets, preserve cash and reduce current liabilities; The Company has a pretty good solvency ratio, to further increase the value of the ratio, the company must increase its capital assets and liabilities, so that companies are able to finance the obligations; Although profitability ratios measured from the industry average in poor condition, but the value of the ratio increase from the previous year. To further improve earnings in the next year, the company should be able to maximize the use of all its assets and capital owned in its operations, in order to produce the desired benefits. So that the profitability ratios could increase in the years to come; Companies must perform the calculation of financial ratios every year, which aims to determine the company's financial condition.

\section{References}

Afriyeni, E. (2008). Financial Performance Assessment Using Ratio Analysis. Journal of Economics and Business, 3, 109-118.

Indonesia stock exchange. (2016). Financial Statements and Annual. Picked January 8, 2018, from http://www.idx.co.id/id-id/beranda/perusahaantercatat/ laporankeuangandantahunan.aspx.

Fahmi, I. (2011). Financial Performance Analysis. Bandung: Alfabeta.

Indonesian Institute of Accountants. (2015). Financial Accounting Standards. Jakarta: IAI.

Kasmir. (2016). Financial Statement Analysis. Jakarta: Rajawali Pers.

Ottay, MC, \& Alexander, SW (2015). Financial Statement Analysis to Assess Financial Performance At PT BPR Citra Dumoga Manado. EMBA Journal, 3, 923-932.

Sujarweni, VW (2017). Financial Statement Analysis. Yogyakarta: New Library Press.

Wibowo, HA, \& Pujiati, D. (2011). Financial Ratio Analysis in Predicting Changes in Profit In Real Estate And Property Company in Indonesia Stock Exchange (BEI) and Singapore (SGX). The Indonesian Accounting Review, 1, 155-178. 